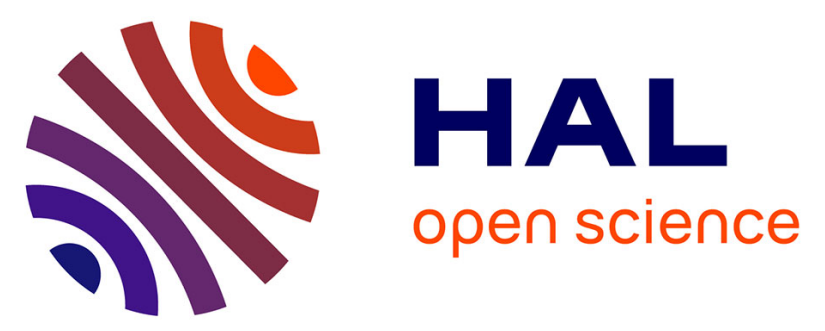

\title{
Forest soil microbial functional patterns and response to a drought and warming event: key role of climate-plant-soil interactions at a regional scale
}

\author{
A. Pailler, M. Vennetier, F. Torre, C. Ripert, D. Guiral
}

\section{- To cite this version:}

A. Pailler, M. Vennetier, F. Torre, C. Ripert, D. Guiral. Forest soil microbial functional patterns and response to a drought and warming event: key role of climate-plant-soil interactions at a regional scale. Soil Biology and Biochemistry, 2014, 70, p. 1 - p. 4. 10.1016/j.soilbio.2013.12.003 . hal-00991404

\author{
HAL Id: hal-00991404 \\ https://hal.science/hal-00991404
}

Submitted on 15 May 2014

HAL is a multi-disciplinary open access archive for the deposit and dissemination of scientific research documents, whether they are published or not. The documents may come from teaching and research institutions in France or abroad, or from public or private research centers.
L'archive ouverte pluridisciplinaire HAL, est destinée au dépôt et à la diffusion de documents scientifiques de niveau recherche, publiés ou non, émanant des établissements d'enseignement et de recherche français ou étrangers, des laboratoires publics ou privés. 
Author-produced version of the article published in Soil Biology and Biochemistry, (70): 1-4, 2014.

Original publication available at http://www.sciencedirect.com

doi : 10.1016/j.soilbio.2013.12.003

Pailler A., Vennetier M., Torre F., Ripert C., Guiral D., 2014. Soil Biology and Biochemistry, (70): 1-4.

\title{
Forest soil microbial functional patterns and response to a drought and warming event: key role of climate-plant-soil interactions at a regional scale
}

\author{
Alexia Pailler, ${ }^{a}$ Michel Vennetier, ${ }^{\mathrm{b}}$ Franck Torre, ${ }^{\mathrm{a}}$ Christian Ripert $^{\mathrm{b}}$ and Daniel Guiral ${ }^{\mathrm{a}}$
}

Corresponding author: Alexia Pailler, Institut Méditerranéen de Biodiversité et d'Ecologie marine et continentale (IMBE, UMR CNRS 7263-IRD 237), Aix-Marseille University, FST St Jérôme, Boîte 421, F 13397 Marseille Cedex 20, France; Tel. (+33) 491288 528; Fax (+33) 491288 668; E-mail alexia.pailler@imbe.fr.

a Institut Méditerranéen de Biodiversité et d'Ecologie marine et continentale (IMBE, UMR CNRS 7263IRD 237), Aix-Marseille University, FST St Jérôme, Boîte 421, F 13397 Marseille Cedex 20, France.

${ }^{b}$ Institut national de recherche en sciences et technologies pour l'environnement et l'agriculture (IRSTEA), Aix en Provence, CS 40061, 13182 Aix en Provence Cedex 5, France.

\begin{abstract}
Little is known about how spatial and environmental patterns structure soil microbial activities. We investigated, on 47 soil samples collected in Mediterranean forests, the net and interaction effects of climatic-geographic and edaphic variables as well as vegetation cover and composition on soil microbial community-level physiological profiles (CLPPs) assessed by Microresp ${ }^{\mathrm{TM}}$. The effects of these variables were also analyzed on CLPP response to an experimental drought treatment. CLPPs were shown to be mainly driven by climate-plant-soil and plant-soil interactions; even after drought treatment, there was a decrease in microbial activity but no change in CLPPs. Our findings highlight the robustness of these relationships, which need to be assessed within different ecosystems considering various spatial scales to reliably predict climate change effects on terrestrial ecosystems.
\end{abstract}

Keywords: CLPP; Microresp ${ }^{\mathrm{TM}}$; Mediterranean soils; aboveground-belowground interactions.

It remains difficult to predict the responses of plant and microbial community relationships to climate change (Bardgett et al., 2008), partly due to lack of knowledge about the deterministic factors of the soil microbial functional patterns directly linked to ecosystem processes (Green et al., 2008; Griffiths et al., 2011). Focusing on Mediterranean forest ecosystems, particularly vulnerable to increased length of summer drought and frequency of heatwaves (IPCC, 2007), the aims of our study were first to assess the environmental surrogates driving soil microbial community-level physiological profiles (CLPPs), and then to determine the robustness of their relationships with environmental surrogates after an experimental ex situ hard "drought" event, like those that occur in Mediterranean regions.

The study area, about $7000 \mathrm{~km} 2$ (long $4^{\circ} 5^{\prime}-6^{\circ} 2^{\prime} \mathrm{E}$, lat $43^{\circ} 4^{\prime}, 43^{\circ} 5^{\prime} \mathrm{N}$ ), is situated in an area of limestone-based soil in Provence, Southeastern France, with a Mediterranean climate (severe summer drought and mild humid winters). Forests are mixed stands of Pinus halepensis Mill., Quercus ilex L. and Quercus pubescens Willd. 47 soils were sampled across the area, covering a bioclimatic gradient (Figure S1) during the 2010 summer drought period, when extreme heatwave events are likely to occur. On each plot $(20 \mathrm{~m} \times 20 \mathrm{~m}), 12$ subsamples from the upper soil horizon $(0-5 \mathrm{~cm})$ were systematically cored along 3 transects $(5,10$ and $15 \mathrm{~m}$ from the border), with 4 subsampling points on each transect at 4, 8, 12 and 16 $\mathrm{m}$. All subsamples of the same plot were pooled to obtain a composite sample. Samples were then sieved at $2 \mathrm{~mm}$, air-dried (due to the length of the sampling period, one month) and stored until analysis.

Soils were rewetted to $70 \%$ water holding capacity (WHC) (identified in pre-testing as optimal value to increase basal respiration in our 47 soils while conserving their variability, as against $30 \%$ and $50 \%$ WHC, data not shown) and incubated at $25^{\circ} \mathrm{C}$ for eight days to standardize and equilibrate them before Time 0 (T0) analysis (Goberna et al., 2005). T0 CLPPs were determined by Microresp ${ }^{\mathrm{TM}}$ measuring substrate-induced respirations (SIR) on eight substrates, glucose (gluc), sucrose (suc), trehalose (treha), D+ cellobiose (cello), glycine (gly), caffeic acid (caff), ellagic acid (ella) and catechol 
Author-produced version of the article published in Soil Biology and Biochemistry, (70): 1-4, 2014.

Original publication available at http://www.sciencedirect.com

doi : 10.1016/j.soilbio.2013.12.003

Pailler A., Vennetier M., Torre F., Ripert C., Guiral D., 2014. Soil Biology and Biochemistry, (70): 1-4.

(cat), following the adapted protocol of Campbell et al. (2003). Briefly, our aim being to compare SIRs of soils subjected to the same solution of substrate instead of their absolute rate of mineralization, we used the lowest water content among our samples to determine concentration of $\mathrm{C}$ substrate solutions; solutions were adjusted to $\mathrm{pH}=7$, a mean value of soil $\mathrm{pH}$ (Table 1), both to minimize chemical artifacts due to carbonate-derived $\mathrm{CO}_{2}$ release and to avoid any substrate-pH effect on microbial communities (Bérard et al., 2011). After T0 measurements, samples were dried for ten days at $50^{\circ} \mathrm{C}$, to obtain "stressed" samples (ST), rewetted and maintained at $70 \%$ WHC, $25^{\circ} \mathrm{C}$ for eight days. Simultaneously, 47 "unstressed" samples (NS), already subjected to the standardization conditions, were maintained at $70 \%$ WHC, $25^{\circ} \mathrm{C}$ throughout. SIRs on both "NS" and "ST" samples were measured in the same way as at T0.

Organic carbon (Corg) and total nitrogen (Ntot) contents, Corg_N ratio, $\mathrm{pH}$ and water holding capacity (WHC), variables constitutive of the EDA compartment, were determined via the usual procedure for soil physicochemical analyses (Forster, 1995). Climatic and geographic variables (CG compartment) presented in Table 1, vegetation composition and structure of each plot (VEG compartment, list of species given Table S1), as well as other EDA variables (Table 1) are based on data from Vennetier et al. (2008) and Vennetier and Ripert (2009).

Table 1: Descriptive statistics of the climatic-geographic (CG) and edaphic (EDA) variables. Soil texture is presented for informative purposes as a percentage of soil samples.

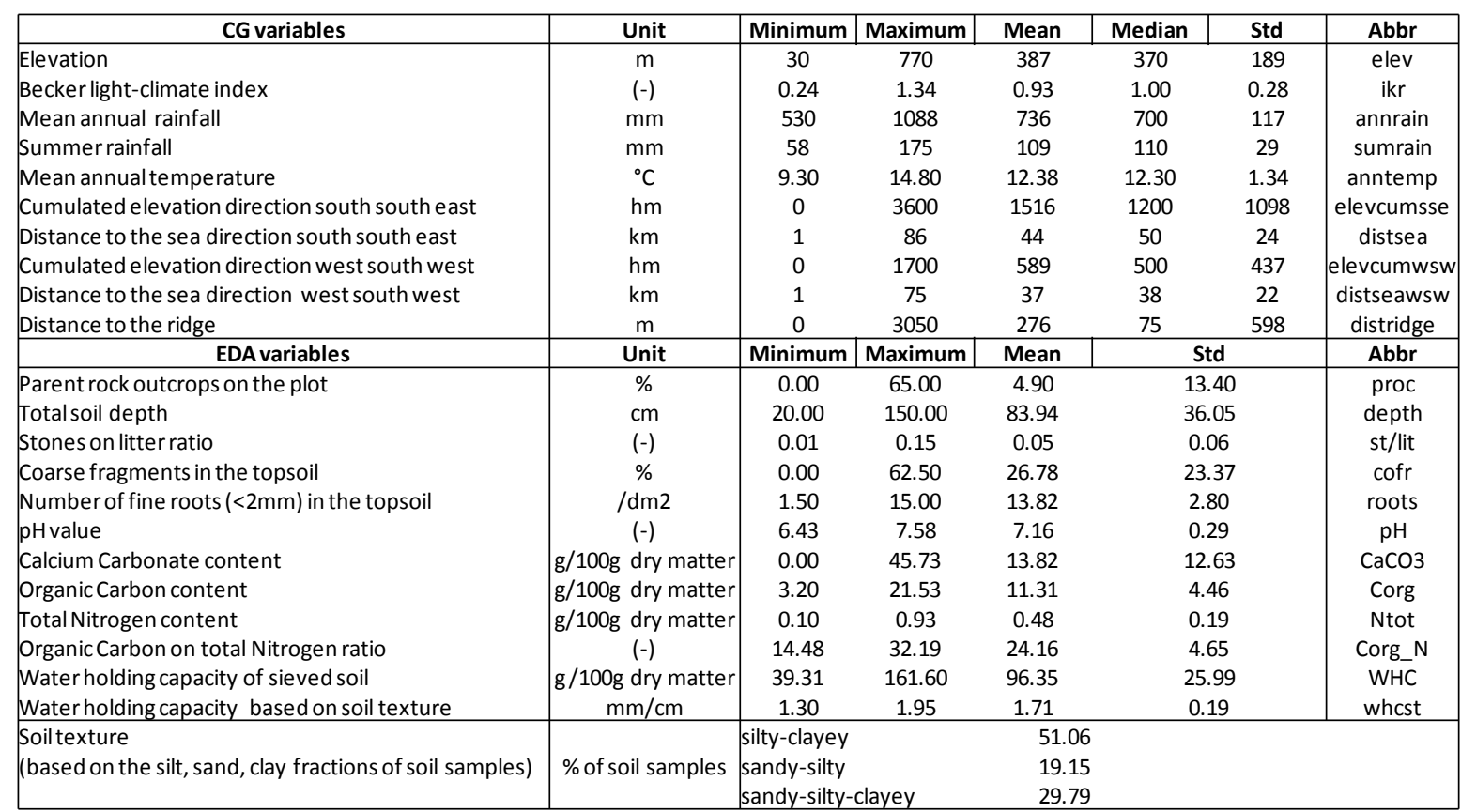

Abbr: abbreviation; Std: standard deviation.

Before statistical analyses, SIRs on each substrate and each sample were standardized by scaling (subtracting the mean SIR of all soils on all substrates, then dividing by the standard deviation). RDA sets combining selected variables from the various compartments and derived adjusted $\mathrm{R}^{2}$ values, followed by both variance partitioning analysis and Monte Carlo permutation tests, were used to assess both their relative impact and their interactions on T0 CLPPs and on their responses to drought. Effects of each compartment (individual effect) were thus broken down into real individual effect (net effect) and effect through their interactions (interaction effect), and synthesized through Venn diagrams. It was not possible to statistically test the significance of the interaction effect. T0, NS and ST CLPPs were compared through PCA. Two-way ANOVA followed by Tukey LSD post hoc tests were performed to assess the effects of interaction between drought treatment (T0, NS, ST) and type of substrate. CLPP response to drought was assessed by computation of the arithmetic difference between ST and NS (R Development Core Team 2012). 
Author-produced version of the article published in Soil Biology and Biochemistry, (70): 1-4, 2014.

Original publication available at http://www.sciencedirect.com

doi : 10.1016/j.soilbio.2013.12.003

Pailler A., Vennetier M., Torre F., Ripert C., Guiral D., 2014. Soil Biology and Biochemistry, (70): 1-4.

RDA results and Venn diagrams showed that although the CG, EDA and VEG compartments all had significant individual effects on initial CLPPs (adjusted $\mathrm{R}^{2}(\%)^{\text {: }}$ CG 20.64, EDA 42.44, VEG 43.47; $\mathrm{p}<0.01$; Figure 1a), their main impact resulted from their interactions (adjusted $\mathrm{R}^{2}$

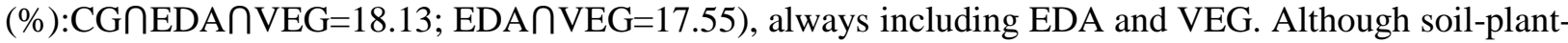
climate interactions are well documented, their effect on CLPP has not previously been shown so clearly at a regional scale, within a single type of ecosystem (Singh et al., 2009; Liu et al., 2010). This may be because our sampling strategy focusing on forest ecosystems excludes de facto any effects of different land use (Drenovsky et al., 2010) and different geological substratum (Fierer and Jackson, 2006).

CLPPs appeared to be mainly discriminated by their SIR on carbohydrates and glycine (axis 1) and complex phenolic compounds (axis 2), depending on forest habitat type (four types described; Figure 2), which resulted in a strong dissimilarity between CLPPs in stands dominated by broadleaved trees (high respiration rates on carbohydrates) and those dominated by coniferous trees (high respiration rates on phenolic compounds). The litter of coniferous species is known to be very rich in recalcitrant polymeric phenolic compounds (Zechmeister-Boltenstern et al., 2011), whose inputs may have selected microbial community with the adequate enzymes to oxidize them. It is also known to decrease soil $\mathrm{N}$ availability and mineralization processes (Hättenschwiller and Vitousek, 2000), which is consistent with our observations. These results highlight the influence of vegetation cover and composition on microbial activity through its influence on soil organic matter quality and quantity, and thereby soil physicochemical properties (Wardle, 2006).

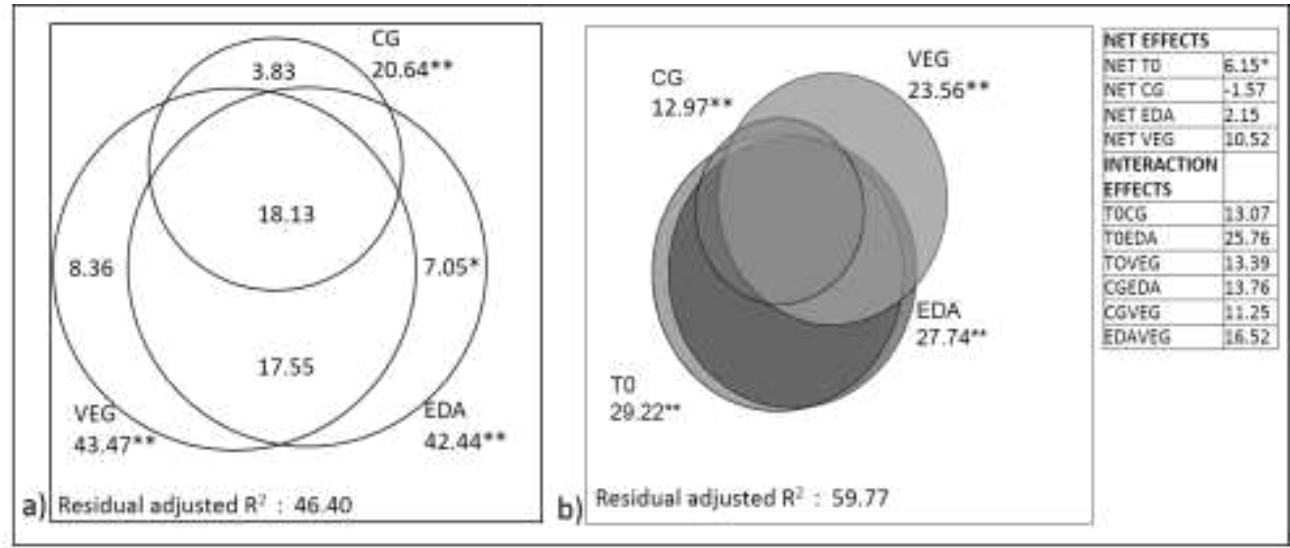

Figure $1 \boldsymbol{a}$ ), $\boldsymbol{b})$ : Venn diagram of the individual, interaction and net effects of a) the various environmental compartments Climatic-geographic (CG), Edaphic (EDA) and Vegetation (VEG) on initial CLPPs (TO); Adjusted R-squared for each part of the circles are indicated with result of Monte -Carlo permutation test $p$ value significance ( $p$ values are not shown; * $p<0.05$; **: $p<0.01$; *** $: p<0.001$ )

b) the various environmental compartments Climatic-geographic (CG), Edaphic (EDA) and Vegetation (VEG), and initial CLPP (TO) on CLPP responses to drought; adjusted R-squared of individual effects are indicated on the diagram with their significance level **: $p<0.01$; net effects and interaction effects are indicated near the diagram with their significance level $(* ; p<0.05)$.

The squares represent $100 \%$ of variance explained. Significance of the impact due to interactions could not be tested. 
Author-produced version of the article published in Soil Biology and Biochemistry, (70): 1-4, 2014.

Original publication available at http://www.sciencedirect.com

doi : 10.1016/j.soilbio.2013.12.003

Pailler A., Vennetier M., Torre F., Ripert C., Guiral D., 2014. Soil Biology and Biochemistry, (70): 1-4.

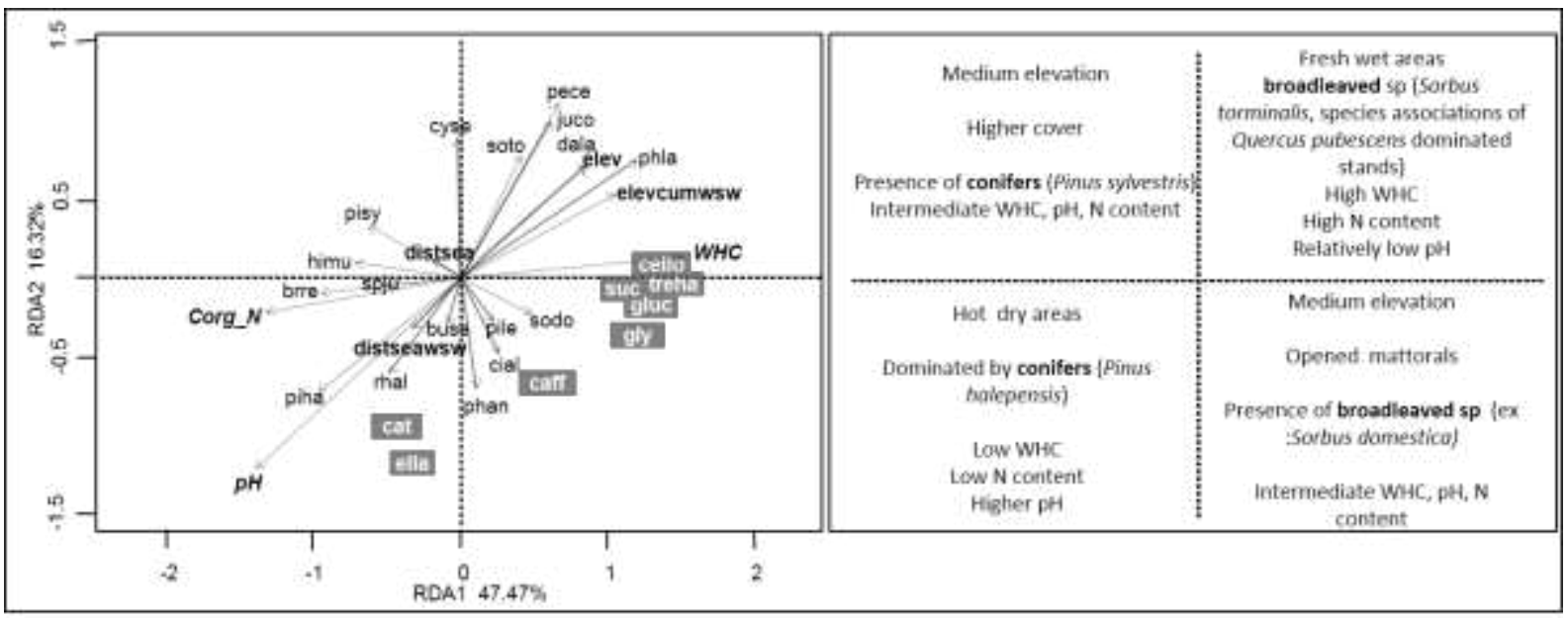

Figure 2: Redundancy analysis (RDA) of the initial CLPP (TO) with respect to Climatic-geographic compartment (CG), Edaphic compartment (EDA) selected variables and Vegetation (VEG) selected plant species. On right is the synthesis of the different habitat types defined according to the associations of the selected variables. Microbial utilization rates of each substrate are in grey; $C G$ selected variables are in bold (elev: elevation; elevcumwsw: cumulated elevation direction west south west; distseawsw: distance to the sea direction west south west); EDA selected variables are in italics; VEG selected species are not in bold and not in italics (cyse: Cytisus sessilifolius; soto: Sorbus torminalis; pece: Peucedanum cervaria; juco: Juniperus communis; dala: Daphne laureola; phla: Phyllirea latifolia; sodo: Sorbus domestica; pile: Pistacia lentiscus; cial: Cistus albidus; phan: Phyllirea angustifolia; buse: Buxus sempervirens; rhal: Rhamnus alaternus; piha: Pinus halepensis; brre: Brachypodium retusum; spju: Spartium junceum; himu: Hieracium murorum; pisy: Pinus sylvestris).

Drought stress induced a decrease in SIR, significant for all substrates except for both catechol, which might have a toxic inhibitory effect on microbial activity (very low respiration rates at T0, NS and ST) (Chen et al., 2009), as well as ellagic acid (Figure 3, p<0.001). The release of $\mathrm{C}$ and nutrients from dead biomass after drought might have been used by surviving microorganisms to enable attack on recalcitrant compounds (Fontaine et al., 2004), which could explain the higher respiration rates observed after drought on the two phenolic acids compared to those on simple compounds. However, there was no major change in CLPP between the ST and the NS or T0 treatments as analyzed by PCA (Figure 3). In addition, CLPP responses to drought were driven by all compartments (adjusted $\mathrm{R}^{2}(\%)$ : $\mathrm{T} 0=29.22$; $\mathrm{CG}=12.97$; $\mathrm{EDA}=27.74$, VEG=23.56; $\mathrm{p}<0.01$ ), and mainly by T0 CLPPs and their interactions with $\mathrm{CG}$, VEG and EDA, explaining 13 to $26 \%$ of variance, neither of which had any net effect (Figure 1b). Moreover, there was no major difference in ranking or numbers among the RDA selected variables after drought treatment compared to T0 (data not shown). More studies would be necessary both, to confirm these trends, and to discriminate the relevant environmental variables driving microbial functional patterns, depending on the type of ecosystem considered. 


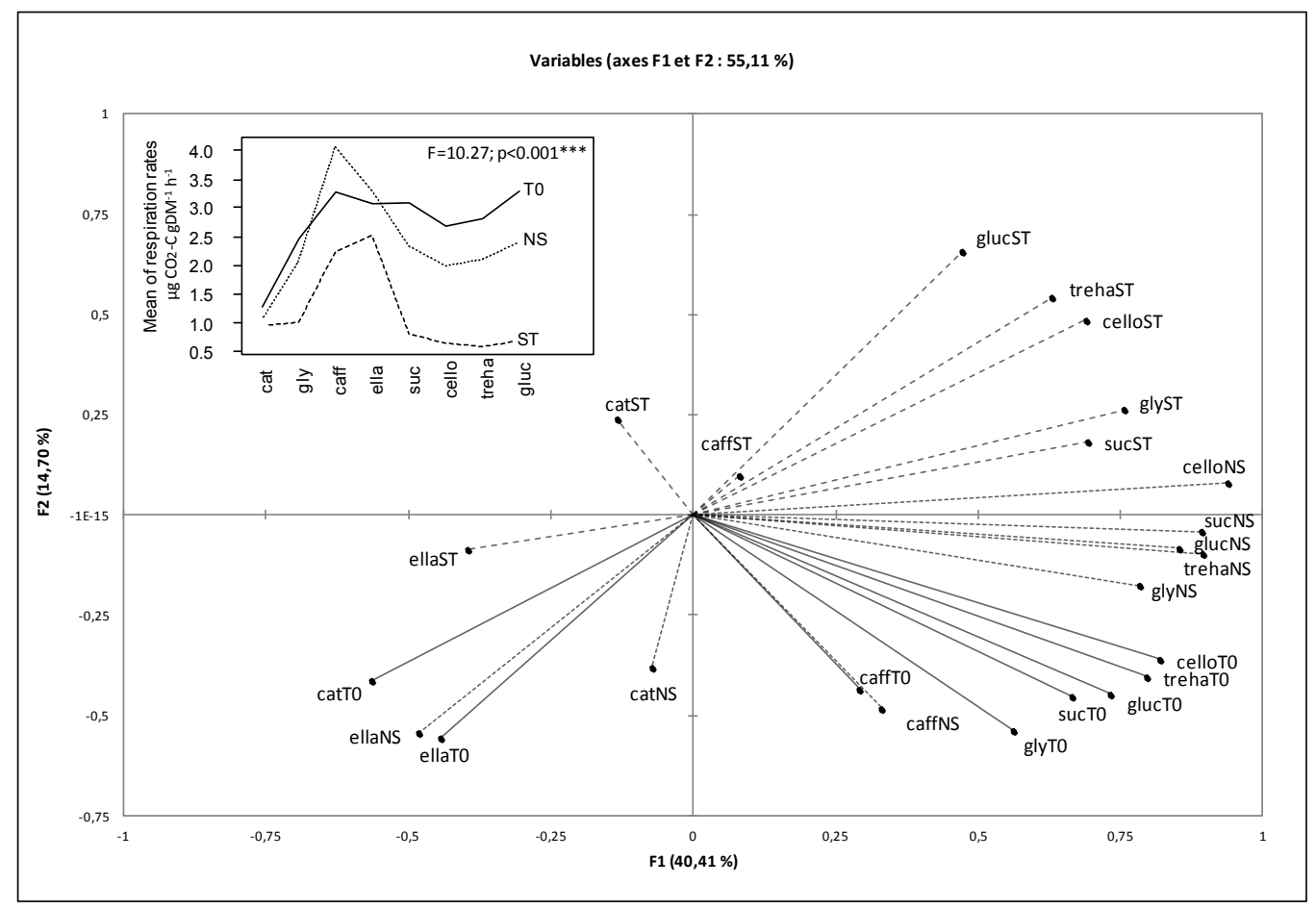

Figure 3: PCA of initial time (TO), unstressed (NS) and stressed (ST) CLPPs with on top left ANOVA results testing interaction effects between drought treatment and substrate used, on SIR of soils at initial time (TO), unstressed soils (NS) and stressed soils (ST). F value and level of significance are indicated on top left. Cat: catechol; gly: glycine; caff: caffeic acid; ella: ellagic acid; suc: sucrose; cello: cellobiose; treha: trehalose; gluc: glucose.

These results illustrate the strength and the robustness of soil microbial community - plant relationships, which may thus mitigate climate change effect on both belowground and aboveground communities, at least as long as vegetation patterns are maintained. Their robustness after such treatment supports the results of Waldrop and Firestone (2006), Ge et al. (2008), Lau and Lennon (2012) and thereby highlights the need to further inquire relationships between soil microbial communities and their environment by assessing the importance of their life history in the face of contemporary disturbance events, so as to reliably predict climate change effects on ecosystem processes.

\section{Acknowledgements}

We thank the two anonymous reviewers for their helpful comments, Max Sarrazin for CHN measurements and Marjorie Sweetko for English language editing. This work was made possible by financial support from the CNRS French Scientific Research National Center, PACA Region and the Luberon Natural Regional Park.

\section{References}

Bardgett, R.D., Freeman, C., Ostle, N. J., 2008. Microbial contributions to climate change through carbon cycle feedbacks. The ISME Journal 2, 805-814.

Bérard, A., Bouchet, T., Sévenier, G., Pablo, A.L., Gros, R., 2011. Resilience of soil microbial communities impacted by severe drought and high temperature in the context of Mediterranean heatwaves. European Journal of Soil Biology 47, 333-342.

Campbell, C.D., Chapman, S.J., Cameron, C.M., Davidson, M.S., Potts, J.M., 2003. A rapid microtiter plate method to measure carbon dioxide evolved from carbon substrate amendments so as to determine the physiological profiles of soil microbial communities by using whole soil. Applied and Environmental Microbiology 69, 3593-3599. 
Author-produced version of the article published in Soil Biology and Biochemistry, (70): 1-4, 2014.

Original publication available at http://www.sciencedirect.com

doi : 10.1016/j.soilbio.2013.12.003

Pailler A., Vennetier M., Torre F., Ripert C., Guiral D., 2014. Soil Biology and Biochemistry, (70): 1-4.

Chen, H., Yao, J., Wang, F., Choi, M. M., Bramanti, E., Zaray, G., 2009. Study on the toxic effects of diphenol compounds on soil microbial activity by a combination of methods. Journal of hazardous materials $167,846-851$.

Drenovsky, R.E., Steenwerth, K.L., Jackson, L.E., Scow, K.M., 2010. Land use and climatic factors structure regional patterns in soil microbial communities. Global Ecology and Biogeography 19, $27-$ 39.

Fierer, N., Jackson, R.B., 2006. The diversity and biogeography of soil bacterial communities. Proceedings of the National Academy of Sciences of the United States of America 103, 626-631.

Fontaine, S., Bardoux, G., Abbadie, L., Mariotti, A., 2004. Carbon input to soil may decrease soil carbon content. Ecology letters 7, 314-320.

Forster, J. C., 1995. Methods in applied soil microbiology and biochemistry. Academic Press, London.

Ge, Y., He, J., Zhu, Y., Zhang, J., Xu, Z., Zhang, L., Zheng, Y., 2008. Differences in soil bacterial diversity: driven by contemporary disturbances or historical contingencies? The ISME Journal 2, 254 264.

Goberna, M., Insam, H., Pascual, J.A., Sanchez, J., 2005. Storage effects on the community level physiological profiles of Mediterranean forest soils. Soil Biology \& Biochemistry, 37, 173-178.

Green, J.L., Bohannan, B.J.M., Whitaker, R.J., 2008. Microbial biogeography: from taxonomy to traits. Science 320, 1039-1043.

Griffiths, R. I., Thomson, B.C., James, P., Bell, T., Bailey, M., Whiteley, A.S., 2011. The bacterial biogeography of British soils. Environmental Microbiology 13, 1642-1654.

Hättenschwiler, S., Vitousek, P. M., 2000. The role of polyphenols in terrestrial ecosystem nutrient cycling. Trends in Ecology \& Evolution 15, 238-243.

IPCC, 2007: Climate Change 2007: Impacts, Adaptation, and Vulnerability. Contribution of Working Group II to the Third Assessment Report of the Intergovernmental Panel on Climate Change. Parry, M.L., Canziani, O.F., Palutikof, J.P., van der Linden, P. J., Hanson, C. E. (Eds.). Cambridge University Press, Cambridge, UK.

Lau, J.A., Lennon, J.T., 2012. Rapid responses of soil microorganisms improve plant fitness in novel environments. Proceedings of the National Academy of Sciences of the United States of America 109 (35), 14058-14062.

Liu, Z.F., Fu, B.J., Zheng, X.X., Liu, G.H., 2010. Plant biomass, soil water content and soil N: P ratio regulating soil microbial functional diversity in a temperate steppe: A regional scale study. Soil Biology \& Biochemistry 42, 445-450.

R Development Core Team, 2012. R: A language and environment for statistical computing. R Foundation for Statistical Computing, Vienna, Austria. ISBN 3-900051-07-0, URL http://www.Rproject.org/.

Singh, B.K., Dawson, L.A., Macdonald, C.A., Buckland, S.M., 2009. Impact of biotic and abiotic interaction on soil microbial communities and functions: a field study. Applied Soil Ecology 41, 239248.

Vennetier, M., Ripert, C., Maillé, E., Blanc, L., Torre, F., Roche, P., Tatoni, T., Brun, J.-J., 2008. A new bioclimatic model calibrated with flora for Mediterranean forested areas. Annals of Forest Science 711 (65).

Vennetier, M., Ripert, C., 2009. Forest flora turnover with climate change in the Mediterranean region: a case study in Southeastern France. Forest Ecology and Management 258, S56-S63.

Waldrop, M.P., Firestone, M.K., 2006. Response of microbial community composition and function to soil climate change. Microbial Ecology 52, 716-724.

Wardle, D.A., 2006. The influence of biotic interactions on soil biodiversity. Ecology Letters 9, 870-886.

Zechmeister-Boltenstern, S., Michel, K., Pfeffer, M., 2011. Soil Microbial Community Structure in European Forests in Relation to Forest Type and Atmospheric Nitrogen Deposition. Plant and Soil 343, $37-50$. 
Author-produced version of the article published in Soil Biology and Biochemistry, (70): 1-4, 2014.

Original publication available at http://www.sciencedirect.com

doi : 10.1016/j.soilbio.2013.12.003

Pailler A., Vennetier M., Torre F., Ripert C., Guiral D., 2014. Soil Biology and Biochemistry, (70): 1-4.

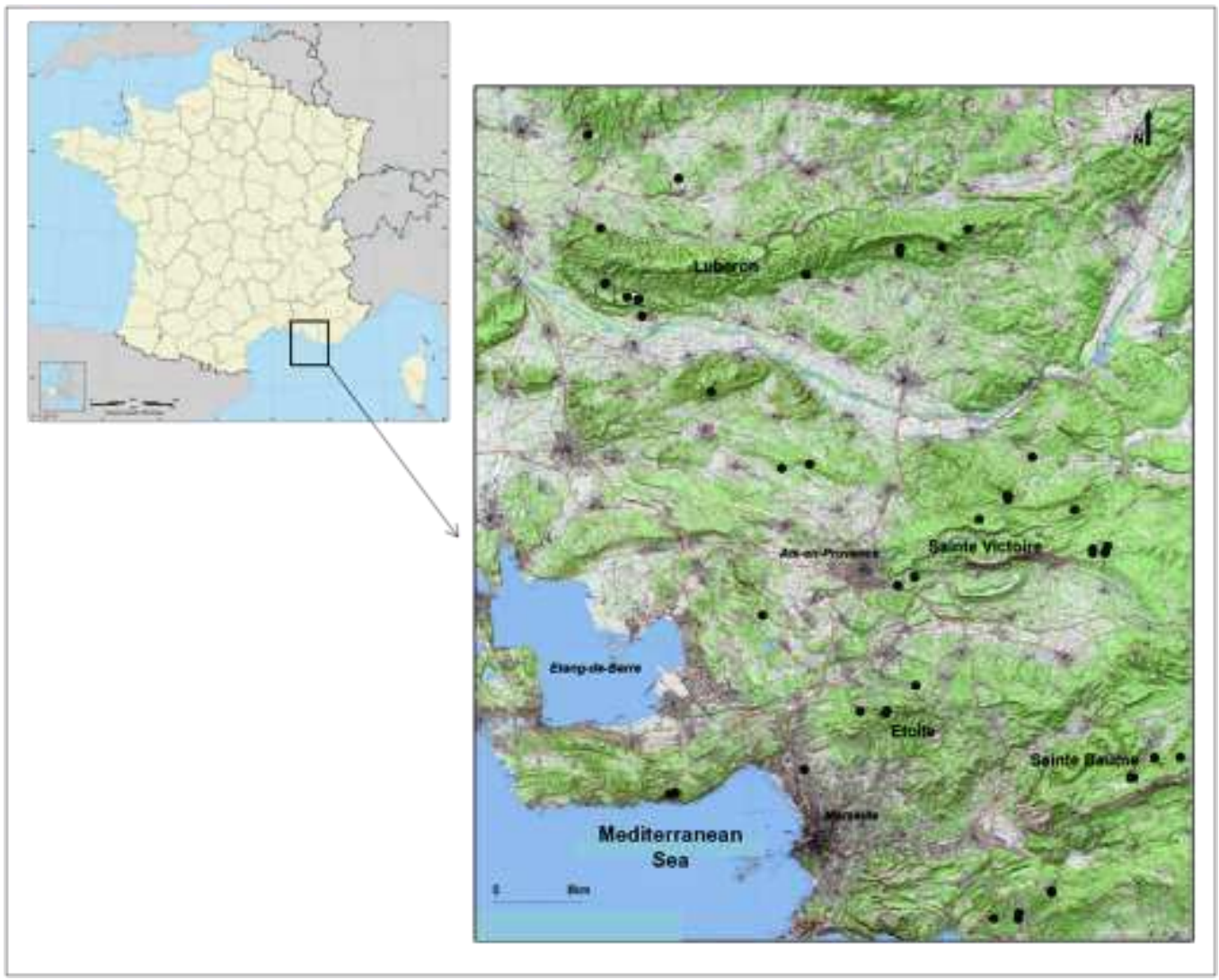

Figure S1 (supporting information): Study area with sampling sites (black circles).

Table S1 (supporting information)

onstitutive species and abbreviations (in bold) of the Vegetation compartment (VEG) used to explain soil microbial functional profiles: Tree species (TREES), Shrub species (SHRUBS) and Herbaceous species (HERBS).

\begin{tabular}{|c|c|c|c|c|}
\hline TREES & Ilex aquifolium ilaq & HERBS & Dorycnium hirsutum dohi & Lonicera implexa loim \\
\hline Acer monspessulanum acmo & Juniperus communis juco & Aphyllanthes monspelliensis apmo & Dorycnium pentaphyllum dope & Onobrychis saxatilis onsa \\
\hline Pinus halepensis piha & Juniperus oxycedrus juox & Arabis hirsuta arhi & Euphorbia characias euch & Ononis minutissima onmi \\
\hline Pinus silvestris pisi & Juniperus phoenicea juph & Argyrolobium zanonii arza & Festuca ovina feov & Osyris alba osal \\
\hline Quercus ilex quil & Olea europaea oleu & Asparagus acutifolius asac & Filipendula vulgare fivu & Peucedanum cervaria pece \\
\hline Quercus pubescens qupu & Phillyrea angustifolia phan & Avena bromoïdes avbr & Galium verum gave & Potentilla hirsuta pohi \\
\hline Sorbus aria soar & Phillyrea latifolia phla & Brachypodium phoenicoides brph & Genista hispanica gehi & Psoralea bituminosa psbi \\
\hline Sorbus domestica sodo & Pistacia lentiscus pile & Brachypodium pinnatum brpi & Genista pilosa gepi & Rubia peregrina rupe \\
\hline Sorbus torminalis soto & Pistacia terebinthus pite & Brachypodium retusum brre & Geranium robertianum gero & Sedum anopetalum sean \\
\hline Taxus baccata taba & Quercus coccifera quco & Bupleurum rigidum buri & Hedera helix hehe & Silene italica siit \\
\hline SHRUBS & Rhamnus alaternus rhal & Carex halleriana caha & Helianthemum hirtum hehi & Smilax aspera smas \\
\hline Amelanchier ovalis amov & Rhamnus saxatilis rhsa & Carex humilis cahu & Helianthemum italicum heit & Staehelina dubia stdu \\
\hline Arbutus unedo arun & Rosa canina roca & Clematis flammula clfl & Hieracium murorum himu & Stipa offneri stof \\
\hline Buxus sempervirens buse & Rosmarinus officinalis roof & Coronilla emerus coem & Hieracium pilosella hipi & Teucrium chamaedrys tech \\
\hline Cistus albidus cial & Rubus ulmifolius ruul & Coronilla juncea coju & Lavandula latifolia lala & Teucrium montanum temo \\
\hline Cornus sanguinea cosa & Ruscus aculeatus ruac & Coronilla minima comi & Lavandula angustifolia laan & Teucrium polium tepo \\
\hline Crataegus monogyna crmo & Spartium junceum spju & Dactylis glomerata dagl & Leuzea conifera leco & Thymus vulgaris thvu \\
\hline Cytisus sessifolius cyse & Ulex parviflorus ulpa & Daphne gnidium dagn & Ligustrum vulgare livu & Viola $s p$ visp \\
\hline Fragaria vesca frve & Viburnum tinus viti & Daphne laureola dala & Lonicera etrusca loet & \\
\hline
\end{tabular}

